I British thoracic and Tuberculosis Association. Controlled trial. Inhaled corticosteroids compared with oral prednisolone in patients starting long term corticosteroid therapy for asthma. Lancel 1975;ii: $469-73$.

2 Bacal E, Patterson R. Long term effects of beclomethasone dipropionate on prednisone dosage in the corticosteroid dependent asthmatic. F Allergy Clin Immunol 1978;62:72-5.

3 Smith MJ, Hodson ME. High dose beclomethasone inhaler in the treatment of asthma. Lance 1983;i:265-9.

Liddle GW. Clinical pharmacology of the anti-inflammatory steroids. Clin Pharmacol Ther 1961;2:615-35

Morris HG. Pharmacology of corticosteroids in asthma. In: Middleton EJ, Reed CE, Ellis EF, eds. Allergv, principles and practice. St Louis: C V Mosby Co, 1978:464-80.

6 Gambertoglio JG. Amend WJC, Benet LZ. Pharmacokinetics and bioavailability of prednisolone and prednisone in healthy volunteers and patients. A review. $\mathcal{I}$ Pharmacokinet Biopharm 1980;8:1-52.

7 Madsbad S, Bjeregaard B, Henriksen JH, Juhl E, Kehlet H. Impaired conversion of prednisone to prednisolone in patients with liver cirrhosis. Gut 1980;21:52-6.

8 Liddle GW. The adren.Is. In: Williams RH, ed. Textbook of endocrinology. 6th ed. Philadelphia: W B Saunders and Co, 1981:249-92.

9 Bordley JE, Carey RA, Harvey AMcG, et al. Preliminary observations on the effect of adrenocorticotropic hormone (ACTH) in allergic diseases. Bulletin of the fohns Hopkins Hospital 1949;85:396-8.

10 Forssmann O, Mulder J. Hypersensitivity to different ACTH peptides. Acta Med Scand 1973;193:557-9.
11 Price J ABC of asthma. Asthma in children: treatment. Br Med f 1984;288:1895-7. 12 Peake MD, Cayton RM, Howard P. Triamcinolone in corticosteroid resistant asthma. Br $\mathcal{F}$ Dis
Chest 1979;73:39-44.

13 Willey RF, Fergusson RJ, Godden DJ, Crompton GK, Grant IWB. Comparison of oral prednisolone and intramuscular depot triamcinolone in patients with severe chronic asthma. Thorax 1984;39:340-4

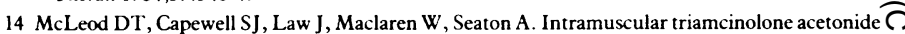
in chronic severe asthma. Thorax 1985;40:840-5.

15 Lerner LJ, Bianchi A, Turkheimer AR, Singer FM, Borman A. Anti-inflammatory steroids. Potency, duration and modification of activities. Ann NY Acad Sci 1964;116:1071-7.

16 Droszcz W, Piotrowska B. Comparison of oral prednisolone and intramuscular depot triamcinolone $\mathbb{S}^{2}$ in patients with chronic severe asthma. Thorax 1985;40:207-8.

17 Mandel S. Steroid myopathy. Postgrad Med 1982;72:207-15

18 Willey RF, Fergusson RJ, Godden D, Crompton GK, Grant IWB. Comparison of oral prednisolone and intramuscular depot triamcinolone in patients with chronic severe asthma. $\vec{~}$ Thorax 1985;40:208.

19 Angeli A, Frajria R, De Paoli R, Fonzo D, Ceresa F. Diurnal variation of prednisolone binding to serum cortico-steroid-binding globulin in man. Clin Pharmacol Ther 1978;23:47-53.

20 Harter JG, Reddy WJ, Thorn GW. Studies on an intermittent corticosteroid dosage regimen. $\frac{\overline{\mathcal{S}}}{\bar{D}}$ NEngl f Med 1963;269:591-6.

21 Fauci AS. Alternate day corticosteroid therapy. Am J Med 1978;64:729-31

\title{
Electrophysiological testing after acute myocardial infarction
}

The long term prognosis in patients surviving acute myocardial infarction depends mainly on the extent of myocardial damage, the residual left ventricular function, the presence and progression of additional coronary artery disease, and the degree of ventricular electrical instability. ${ }^{1-4}$ Attempts to measure the risk need to consider these multiple factors in order to identify the high risk groups, who need treatment, and the low risk groups, who do not. The contribution of exercise testing after myocardial infarction-which identifies inducible ischaemia secondary to occult coronary artery disease-has been extensively investigated and will not be discussed here. ${ }^{5-6}$

Many of the patients who die after an infarction do so suddenly without evidence of reinfarction. ${ }^{7}$ This observation has led to sustained interest in the identification of markers of ventricular electrical instability. A correlation exists between complex ventricular extrasystolic activity (as shown by ambulatory electrocardiographic recording) and the degree of impairment of left ventricular function, ${ }^{8}$ though the two factors are of independent prognostic importance. ${ }^{39}$ The risk of sudden death is increased in patients with frequent ventricular extrasystoles, particularly complex forms, ${ }^{349}$ or runs of non-sustained ventricular tachycardia. ${ }^{10}$ Treatment with antiarrhythmic drugs had been assumed to improve the prognosis of these patients, but the results of trials based on high risk groups have been disappointing despite a substantial reduction in ventricular extrasystolic activity. ${ }^{11} 12$ Several explanations have been advanced for this apparent paradox. The reduction in extrasystoles might not reflect the ability of the drug to prevent sustained ventricular tachycardia or fibrillation, and the designs of the studies did not allow for the increasingly recognised proarrhythmic effect of class I antiarrhythmic drugs in some patients. ${ }^{13}$

These difficulties have stimulated interest in a more direct approach to assessing electrical instability after myocardial infarction using techniques of programmed ventricular stimulation initially evolved for patients with chronic recurrent ventricular tachycardia. ${ }^{14}$ In such cases one or more temporary pacing electrodes are inserted for intracardiac stimulation and recording and an attempt is then made to initiate the tachycardia by introducing single, double, or sometimes triple ventricular extrastimuli during sinus rhythm and ventricular pacing. Most of the tachycardias induced may be terminated by overdrive pacing, but in about $\mathrm{G}$ one fifth of cases cardioversion is necessary. ${ }^{14}$ Once $\mathrm{a}$ tachycardia has been shown to be inducible the patient $\mathscr{C}_{0}$ may be given an antiarrhythmic drug and another attempt 0 made to induce the tachycardia. Several drugs may need to be tested in this way. Clearly this approach provides $\vec{v}$ direct evidence that a given drug prevents the initiation of tachycardia and identifies unwanted proarrhythmic effects, ${ }^{15<}$ and treatment based on the findings has been associated with $\vec{\oplus}$ a reduction in recurrence of tachycardia and an improvement $\%$ in prognosis. ${ }^{16}$

Initial studies using the results of programmed ventricular stimulation as a prognostic index in patients after myocardial infarction have given conflicting results. ${ }^{17-19}$ Some of the $\frac{0}{\Phi}$ variability in results is attributable to the small numbers studied, the selection of patients, and differences in electro- $\overrightarrow{\vec{B}}$ physiological technique. The induction of as few as two consecutive ventricular beats appeared to identify a group at: high risk of sudden death in one study, ${ }^{17}$ while in another report the results of programmed stimulation-even including the initiation of sustained ventricular tachycardiaappeared to provide no prognostic information whatsoever. ${ }^{19} 3$ A similar lack of predictive value was reported in a series of $\delta$ 267 patients with coronary artery disease who were tested $₹$ during routine arteriography. ${ }^{20}$

Denniss and his coworkers from Sidney have recently published a study in which they assessed both electrical instability and inducible ischaemia as determinants of sur-o vival after recent infarction. ${ }^{21}$ From a total of 375 consecutiveñ survivors of acute myocardial infarction, 111 patients were N excluded for reasons including recurrent angina, uncon- 0 trolled heart failure, late ventricular tachyarrhythmias, and age. These exclusions are important: the one year mortality in the excluded patients was $22 \%$ compared with $10 \%$ in the $\stackrel{?}{+}$ study group. The remaining 228 patients were investigated $\frac{0}{3}$ by programmed ventricular stimulation and treadmill exercise testing, though both procedures were undertaken in only $\stackrel{\odot}{\mathbb{D}}$ 138 patients. Treatment with antiarrhythmic drugs was not $\frac{\varrho}{\sigma}$ given on the basis of the results of programmed stimulation but only for spontaneous arrhythmias. Electrical instabilityo응 was shown in 38 patients and their one year mortality was $26 \%$ compared with $6 \%$ in the remainder. The combination of negative results from the electrophysiological and exercise? 
tests identified a subgroup of 85 patients at very low risk $(1 \%$ mortality).

Is identification of a potential for ventricular tachycardia in the convalescent phase of myocardial infarction of any practical clinical importance? The answer at present must be no. Unless a randomised controlled trial of treatment with antiarrhythmic drugs in electrically unstable patients is shown to improve their prognosis the procedure is of academic interest only. Even if the results of such a trial were positive the use of an uncomfortable, potentially hazardous procedure requiring highly trained personnel is clearly impracticable for screening. Alternative noninvasive methods of preliminary screening can identify patients at high risk of sudden arrhythmic death. The most promising techniques are ambulatory electrocardiography, determination of the ejection fraction by radionuclide ventriculography, ${ }^{9}$ and recording areas of delayed ventricular activation ("late potentials") from highly amplified, signal averaged electrocardiograms. ${ }^{22}$ Once these techniques have been applied patients identified as at high risk might then be candidates for electrophysiological testing to determine effective treatment and to exclude drug related proarrhythmic effects.

STUART M COBBE

Walton Professor of Medical Cardiology,

Royal Infirmary,

Glasgow G31 2ER

I Norris RM, Barnaby PF, Brandt PWT, et al. Prognosis after recovery from first acute myocardial infarction: determinants of reinfarction and sudden death. Am J Cardiol 1984;53:408-13. Taylor GJ, Humphries JO, Mellits ED, et al. Predictors of clinical course: coronary anatomy and left ventricular function after recovery from acute myocardial infarction. Circulation 1980;62: $960-70$
3 Mukharii J, Rude RE, Poole WK, et al. Risk factors for sudden death following acute myocardial infarction (two year follow-up). Am f Cardiol 1984;54:31-6.

4 Ruberman W, Weinblatt E, Goldberg JD, Frank CW, Chaudhary BS, Shapiro S. Ventricular premature complexes and sudden death after myocardial infarction. Circulation 1981;64 297-305.

Theroux P, Waters DD, Halphen C, Debaisieux JC, Mizgala HF. Prognostic value of exercise testing soon after myocardial infarction. N Engl f Med 1979;301:341-5.

6 Weld FM, Chu KL, Bigger JT, Rolnitzky LM. Risk stratification with low-level exercise testing 2 weeks after acute myocardial infarction. Circulation 1981;64:306-14.

7 Moss AJ, Davis HT, Decamilla J, Bayer LW. Ventricular ectopic beats and their relation to sudden and non-sudden cardiac death after myocardial infarction. Circulation 1979;60: 998-1003.

8 Schulze RA Jr, Strauss HW, Pitt B. Sudden death in the year following myocardial infarction: relation to ventricular premature contractions in the late hospital phase and left ventricular relation to ventricular premature contractions

9 Bigger JT, Fleiss JL, Kleiger R, Miller JP, Rolnitsky LM, Multicenter Post-Infarction Group. The relationship between ventricular arrhythmias, left ventricular dysfunction and mortality in the 2 years after myocardial infarction. Circulation 1984;69:250-8.

10 Bigger JT, Weld FM, Rolnitsky LM. Prevalence characteristics and significance of ventricular tachycardia (three or more complexes) detected with ambulatory electrocardiographic recording in the late hospital phase of acute myocardial infarction. Am $\mathcal{J}$ Cardiol. 1981;48:815-23.

11 Chamberlain DA, Jewitt DE, Julian DG, et al. Oral mexiletine in high risk patients after myocardial infarction. Lancet 1980;ii:1324-7.

12 Van Durme JP, Hagenmeijer F, Bogaert M, et al. Chronic antidysrhythmic therapy after myocardial infarction. Design of Gent-Rotterdam aprindine study. In: Boissel JP, Kumt CR, eds. Multicenter controlled trials: principles and practice. Paris: Inserm, 1977:43.

13 Velebit V, Podrid P, Lown B, Cohen BH, Graboys TB. Agravation and provocation of ventricular arrhythmias by antiarrhythmic drugs. Circulation 1982;65:886-93.

14 Horowitz LN, Josephson ME, Kastor JA. Intracardiac electrophysiologic studies as a method for the optimization of drug theraphy in chronic ventricular arrhythmia. Prog Cardiovasc Dis 1980;23:81-9.

15 Poser RF, Podrid PJ, Lombardi F, Lown B. Aggravation of arrhythmia induced with antiarrhythmic drugs during electrophysiologic testing. Am Heart f 1985;110:9-16.

16 Swerdlow CD, Winkle RA, Mason JW. Determinants of survival in patients with ventricular tachycardia. N Engl F Med 1983;308: 1436-42.

17 Greene HL, Reid PR, Schaeffer AH. The repetitive ventricular response in man. A predictor of sudden death. N Engl J Med 1978;299:730-4.

18 Hamer A, Vohra J, Hunt D, Sloman G. Prediction of sudden death by electrophysiological studies in high risk patients surviving acute myocardial infarction. Am 7 Cardiol 1982;50:223-9.

19 Marchlinski FE, Buxton AE Waxman $\mathrm{HL}$, Josephson ME. Identifying patients at risk of sudden death after myocardial infarction: value of the response to programmed stimulation, degree of death after myocardial infarction: value of the response to programmed stimulation, degree of ventricular ectopic

20 Treese N, Pop T, Meinertz T, et al. Prognostic significance of repetitive ventricular response in chronic coronary artery disease. Eur Heart 7 1985;6:594-601.

21 Denniss AR, Baaijens $\mathrm{H}$, Cody DV, et al. Value of programmed stimulation and exercise testing in predicting one year mortality after acute myocardial infarction. Am $\mathcal{F}$ Cardiol 1985;56:213-20

22 Breithardt G, Schwarzmaier J, Borggrefe K, Haerten K, Seipel L. Prognostic significance of late ventricular potentials after acute myocardial infarction. Eur Heart $\mathcal{f}$ 1983;4:487-95.

\section{Hearing and memory in anaesthetised patients}

The past year or two has seen an increase in medicolegal interest in awareness during anaesthesia. Many legal actions are said to be expected, notably from women who claim they were conscious and able to remember events during general anaesthesia for caesarean section. ' Last year was also the 100th anniversary of the publication of the first scientific study on memory by Ebbinghaus. He found that the capacity of what is now called short term memory is limited to about seven syllables, which, unless transferred to long term memory, persist with decreasing intensity in consciousness until pushed out of awareness by succeeding events. ${ }^{2}$ Only a very small amount of information which evokes a neural response will be stored in the long term memory. Information held in long term memory is wholly unconscious: we become aware of what is there only by transferring small proportions of it into conscious memory. Furthermore, some information stored in long term memory probably cannot be retrieved into working memory. Recent research on hearing and registration in long term memory during general anaesthesia is relevant to the medicolegal problem, and this is an appropriate time to discuss this subject.

As the depth of a general anaesthetic is increased the patient's state changes: from, firstly, conscious awareness with normal recall from long term memory to, secondly, conscious awareness with grossly impaired recall of perioperative events to, thirdly, urconscious awareness, where some stimuli perceived by the brain may be stored in the long term memory but do not subsequently enter consciousness. Finally, perception of stimuli by the brain is severely attenuated, and registration in both short term and long term memory is ablated.

At present the anaesthetist's main source of information on the depth of anaesthesia is the patient's somatic and autonomic responses to surgical stimuli. These responses are modified by neuromuscular blocking drugs and drugs affecting the autonomic nervous system (for example, anaesthetic agents and drugs acting on the cardiovascular system). The presence or absence of these responses does not, however, correlate with conscious awareness ${ }^{3}$ and they are inadequate indicators of a satisfactory depth of anaesthesia. Anaesthetic agents also have amnesic effects, as do drugs such as diazepam, hyoscine, ${ }^{4}$ and lorazepam, which are used perioperatively but which have little effect on conscious awareness.

Two questions need to be addressed. Firstly, is conscious awareness during anaesthesia a frequent event but one which is rarely recalled because of the amnesic effects of perioperative drugs? Secondly, can the depth of anaesthesia be measured objectively so as to eliminate the likelihood of either conscious or unconscious awareness?

The possibility that very light general anaesthesia might exert an important effect on memory was suggested by 